\title{
O HAICAI DE PAULO LEMINSKI COMO RECURSO NO ENSINO DA LITERATURA
}

\author{
Sérgio Roberto MASSAGLI \\ Maiara Cristina MARAFON
}

\begin{abstract}
RESUMO
Considerando os problemas encontrados ao tentar inserir o aluno na cultura literária, este artigo reflete sobre a importância de se trabalhar o haicai de Paulo Leminski no ensino de literatura nas aulas de Língua Portuguesa como estratégia, visando cultivar o gosto pela leitura literária nos jovens leitores. Para tanto, investiga-se a postura que o professor pode adotar em sala de aula em relação ao aluno, bem como a importância dessa postura na constituição de sua subjetividade como leitor, tendo em vista a importância do texto literário como fator de humanização e de desenvolvimento da sensibilidade, da imaginação e do pensamento crítico. Mapeia-se também as origens do gênero no Japão, passando pela sua introdução no Brasil até chegar ao estilo de Paulo Leminski. Por fim, são analisados alguns de seus haicais para demonstrar como esse gênero breve pode ser usado para se trabalhar a literatura no ensino.
\end{abstract}

PALAVRAS-CHAVE: Paulo Leminski; haicai; ensino de literatura; letramento literário.

\section{PAULO LEMINSKI'S HAIKU AS A TEACHING TOOL IN LITERARY READING CLASSES}

\begin{abstract}
Considering problems found in inserting students in literary culture, this article reflects on the importance of working Paulo Leminski's haiku in literaturary reading classes as a strategy to cultivate the taste for literary reading in young readers. Therefore, it investigates the attitude regarding students teachers could adopt in the classroom, as well as how this attitude can affect in the constitution of their subjectivity as readers, taking into account the importance of the literary text as a factor of humanization and development of sensitivity, imagination and critical thinking. A brief survey of the origins of the genre in Japan was made, in order to map from its origins in Japan to its introduction in Brazil, until reaching the style of Paulo Leminski. Finally, some Leminsk's haikus are analysed to demonstrate how this brief genre can be used to work in literary reading classes.
\end{abstract}

KEYWORDS: Paulo Leminski; haiku; teaching of literature; literary literacy.

\section{EL HAIKU DE PAULO LEMINSKI COMO HERRAMIENTA DE ENSEÑNANA EN CLASES DE LITERATURA.}

\begin{abstract}
RESUMEN
Considerando los problemas encontrados al insertar estudiantes en la cultura literaria, este artículo reflexiona sobre la importancia de trabajar el haiku de Paulo Leminski en las clases de lectura literaria como una estrategia para cultivar el gusto por la lectura literaria en lectores jóvenes. Por lo tanto, investiga la actitud con respecto a los estudiantes que los maestros pueden adoptar en el aula, así como también cómo esta actitud puede afectar la constitución de su subjetividad como lectores, teniendo en cuenta la importancia del texto literario como factor de humanización y desarrollo de la sensibilidad. , imaginación y pensamiento crítico. Se realizó una breve encuesta sobre los orígenes del género en Japón, con el fin de mapear desde sus orígenes en Japón hasta su introducción en Brasil, llegando finalmente el estilo de Paulo Leminski. Finalmente, se analizan algunos haikus de Leminsk para demostrar cómo se puede utilizar este breve género para trabajar en clases de lectura literaria.
\end{abstract}

PALABRAS CLAVE: Paulo Leminski; haiku; enseñanza de la literatura; alfabetización literaria.

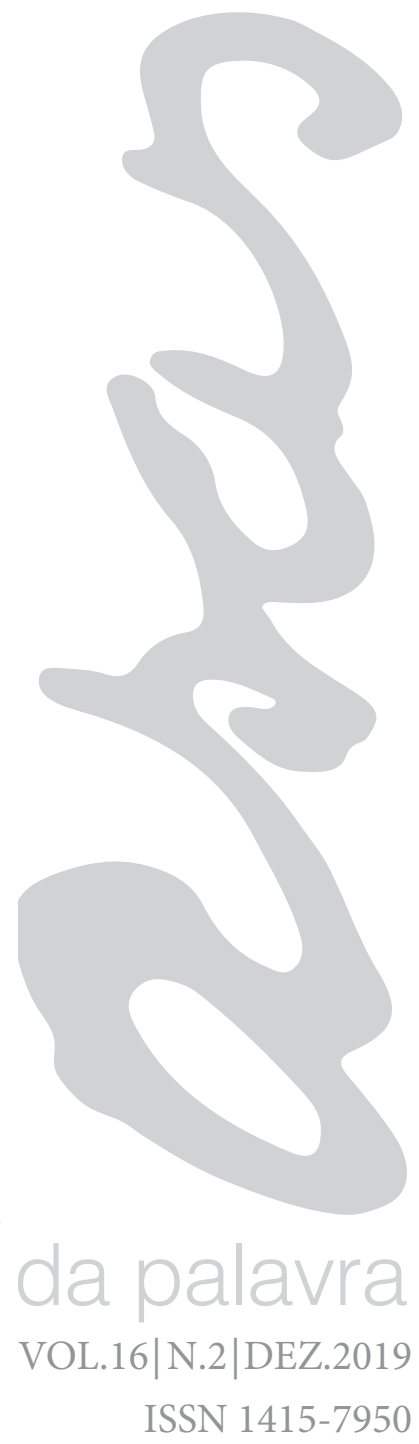




\section{INTRODUÇÃO}

Um dos problemas que se apresenta no ensino de Língua Portuguesa é a dificuldade de inserir o aluno na cultura letrada, de modo que ele possa se apropriar de textos literários por meio da experiência estética, considerando especialmente os textos do gênero lírico. No que tange à leitura de poesia, o desafio na formação do leitor se avulta devido aos recursos um tanto quanto complexos inerentes a sua linguagem, como a ambiguidade, o abstrato, o inacabado, etc. Por outro lado, a baixa frequência na leitura de textos poéticos na escola e o pouco espaço na literatura contemporânea, como se pode perceber a partir de uma rápida pesquisa nas estantes das livrarias ou nas listas dos livros mais vendidos, apontam para uma marginalização da poesia.

A leitura literária no espaço escolar tem tido cada vez mais seu espaço diminuído ou fragmentado, como, por exemplo, ao considerála como apenas mais uma dentre as inúmeras práticas discursivas, ou como mera ilustração/pretexto para outros conteúdos, ou ainda ao se substituir a leitura de obras completas, o que contribuiria para uma ampla experiência literária, por resumos ou compilações destas obras. Daí a necessidade de se investir no letramento literário, como preconizam as Orientações Curriculares para o Ensino Médio:

Contrariamente ao que ocorreu com a alfabetização, que se vem ampliando cada vez mais, a leitura de Literatura tem-se tornado cada vez mais rarefeita no âmbito escolar, como bem observou Regina Zilberman (2003, p. 258), seja porque diluída em meio aos vários tipos de discurso ou de textos, seja porque tem sido substituída por resumos, compilações, etc. Por isso, faz-se necessário e urgente o letramento literário: empreender esforços no sentido de dotar o educando da capacidade de se apropriar da literatura, tendo dela a experiência literária (BRASIL, 2006, p. 55).

Além disso, quando a prática em sala de aula tem o poema como o objeto de ensino, o que se vê é um trabalho que tem como foco as questões gramaticais de um ensino tradicional e a escolarização inadequada da poesia, utilizada somente como fins didáticos, tendo como efeito indesejado o afastamento dos jovens leitores em relação a esse gênero.

Estudada, lida e "praticada" [...] a poesia na escola tem tido pouco a oferecer para seus leitores, que dificilmente conseguem perceber suas particularidades. Os aspectos texto passam quase despercebidos durante a execução 
dessas atividades, que têm mais servido para distanciar o leitor dos poemas do que fazê-lo distrair-se e evadirse através deles (ZAPPONE, 2010, p. 152).

Por isso, torna-se imprescindível, para o aluno, vivenciar a experiência estética por meio da poesia, dentro de uma perspectiva que ao mesmo tempo valorize a autonomia do texto poético enquanto objeto lúdico fechado em si mesmo e a sua transitividade com o mundo, uma vez que mediante o contato com o texto poético ele tem a chance de experimentar a sensação de estranhamento, a qual, por sua vez, proporciona um aguçamento de sua sensibilidade e contribui para ampliar sua visão de mundo. Assim fazendo, a elevação do nível de abstração e das exigências das competências leitoras proporciona um processo contínuo e dinâmico de realização de significados em que o prazer de ler reencontra o seu sentido social.

\section{O LUGAR DO LETRAMENTO LITERÁRIO NO ENSINO DE LÍNGUA PORTUGUESA E O PAPEL DO PROFESSOR}

A leitura é um importante meio pelo qual o sujeito reconhece, interpreta e compreende o mundo, podendo ser entendida a partir de três perspectivas que se interpenetram, como: habilidade fundante do ser humano; como prática social; e como ato de co-produção de textos (DELL'ISOLA, 1994). Ela é indispensável para a construção dos sentidos, é o momento em que o leitor entabula um jogo de significados com o texto. Portanto, para que esse diálogo se estabeleça, é preciso que haja uma interação entre o leitor e o texto. Na leitura de textos não literários (em que pese a dificuldade em definir o que seja a literariedade de um texto), essa interação se esgota quase sempre no plano do significado, isto é, do que o texto quer dizer. A literatura, entretanto, é uma arte que leva à fruição estética, uma vez que ela possui um tipo de liberdade em que as palavras geram novos significados que se abrem em leque na polissemia dos signos, "tirando a trava do sentido, pondo a leitura em roda livre" (BARTHES, 1988, p. 51) num jogo dialético em que significantes e significados estão umbilicalmente imbricados.

Além disso, juntamente com o prazer estético, ela amplia o sentido ético da existência humana ao alargar os valores culturais do leitor e agir como um meio de humanização do homem. A esse propósito, Antonio Candido entende o desenvolvimento da humanização como um 
[...] o processo que confirma no homem aqueles traços que reputamos essenciais, como o exercício da reflexão, a aquisição do saber, a boa disposição para com o próximo, o afinamento das emoções, a capacidade de penetrar nos problemas da vida, o senso da beleza, a percepção da complexidade do mundo e dos seres, o cultivo do humor. A literatura desenvolve em nós a quota de humanidade na medida em que nos torna mais compreensivos e abertos para a natureza, a sociedade, o semelhante. (CANDIDO apud BRASIL, 2006, p. 54).

Para Candido, este ato ou efeito de humanizar, que muda o comportamento e atitudes do homem fazendo-o evoluir, compreende a formação ética, o desenvolvimento intelectual e o pensamento crítico. A vivência singular do jovem leitor com o texto propicia que ele não apenas desenvolva sua capacidade intelectual, sendo capaz de interpretar e atualizar os sentidos daquilo que lê na dimensão informativa do significado, mas também na riqueza sensorial do significante, apropriando-se, assim, do texto literário de maneira mais completa. Em outras palavras, ler é mais do que querer saber o que um texto diz, é querer saber como ele o diz e inclusive querer saber o que ele não diz, ou nas palavras de Orlandi (1999, p. 11): "Saber ler é saber o que o texto diz e o que ele não diz, mas o constitui significativamente".

Portanto, nessa interdependência entre conteúdo e forma, compreende-se que o ato da leitura está vinculado tanto à fruição estética, como à cognição e ao senso crítico. A experiência literária se dá pelo contato efetivo com o texto, mais especificamente com a estrutura que o texto literário oferece à contemplação, por meio do uso incomum da linguagem. A experiência obtida com esse duplo movimento entre significante e significado amplia os horizontes de expectativas do leitor, excita sua imaginação, atiça a sua curiosidade, leva-o a desnaturalizar os fatos e proporcionando, enfim, a possibilidade de um tipo de conhecimento que, diferentemente do conhecimento objetivo, não pode ser mensurável.

Nas Orientações Curriculares para o Ensino Médio, encontramos a definição de letramento de Magda Soares: "letramento: estado ou definição de quem não apenas sabe ler e escrever, mas cultiva e exerce as práticas sociais que usam a escrita" (SOARES apud BRASIL, 2006, p. 55), o que pressupõe deverem estar a leitura e a escrita incorporadas no dia-a-dia nas práticas sociais, a fim de tornar os alunos leitores e escritores proficientes, tanto dentro, quanto fora do espaço escolar. 
dentro de uma concepção de leitura literária que os privilegie como co-participantes do processo criativo da obra literária. Para que haja a produção de sentido do texto, o leitor deve mobilizar, no ato da leitura, suas experiências, as quais, ao inteirar-se com os campos de criação do autor e do texto, poderão gerar possibilidades inesgotáveis de leituras. A respeito dessa concepção de leitor, Jauss, em a História da Literatura como provocação à teoria literária (1994), sustenta que "A história da literatura é um processo de recepção estética que se realiza na atualização dos textos literários por parte do leitor que os recebe" (p. 25). Nesta perspectiva, o leitor dialoga com a obra a partir de suas experiências, seja de mundo ou estéticas, cria hipóteses e busca confirmações por meio das suas referências extralinguísticas e dos vestígios deixados pelo autor, para enfim construir um sentido para o seu texto.

Nesse processo há de se considerar que o professor é antes de tudo um leitor. É ele um modelo de leitor para os seus alunos e sua prática de leituras em classe pressupõe um conhecimento da produção literária, bem como saberes teóricos mais específicos que lhe instrumentalizam para realizar e estimular a atividade crítica requerida pela leitura literária. Nesse sentido, Pilati afirma que

\begin{abstract}
Antes de sermos professores (isto é: mediadores de produções de leitura), nosso compromisso é nos comportarmos como exigentes, dedicados e minuciosos críticos literários. A atividade crítica precede a atividade docente e a atravessa no momento do contato com os estudantes (PILATI, 2017, p. 62).
\end{abstract}

Para que haja um letramento literário satisfatório, a formação e a postura que o professor deve ter, para que favoreça a interação do leitor com a obra nas aulas de Língua Portuguesa, deve estar no centro das reflexões nos cursos de formação, inicial e continuada, dos professores de LP. No artigo Mutações epistemológicas e o ensino da literatura: o advento do sujeito leitor, Annie Rouxel vê a formação do professor como um momento de reflexão e experimentação. Para ela, "a formação dos professores é frequentemente apresentada como a interface entre a pesquisa e a classe" (2012, p. 21), e completa ainda que é interessante os professores integrarem a pesquisa ao ato didático como "meio de lutar contra o dogmatismo e o aplicacionismo que reificam as práticas, privando-as de sentido" (2012, p. 21). 
O professor deve, em sua formação, como leitor, refletir sobre as suas experiências literárias e também a de seus alunos, construindo uma cultura literária através das indagações que venham a surgir destas relações com a literatura. Dar ouvido ao aluno em suas interpretações também está dentre uma das posturas que o professor deve tomar; afinal, é neste momento que ele entra em contato com o conhecimento prévio de mundo do aluno e conhece sua visão, dando importância inclusive às "interpretações divergentes (...) interessantes na medida em que refratam a imagem dos leitores reais, nos informando sobre os obstáculos encontrados", e não se trata somente de o professor ouvir o aluno, mas também deve haver uma "escuta mútua entre os alunos" (ROUXEL, 2012, p. 21).

Percebe-se, portanto, a importância de o professor investir na leitura de poesia, tendo em vista seu potencial de liberação das faculdades criativas do leitor, pois nos textos do gênero lírico nota-se a predominância dos sentimentos e emoções, e sua leitura inevitavelmente contribui para a constituição da subjetividade do leitor. Em Teoria da Literatura, de Vítor Manuel de Aguiar e Silva, lê-se que a poesia é um gênero cujo conteúdo, segundo Hegel (1944):

não é o desenvolvimento de uma acção objectiva alargando-se até os limites do mundo, em toda a sua riqueza, mas o sujeito individual e, por conseguinte, as situações e os obejctos particulares, assim como a maneira segundo a qual a alma, com seus juízos subjectivos, as suas alegrias, as suas admirações, as suas dores e as suas sensações, toma consciência de si própria no seio deste conteúdo. (Hegel apud AGUIAR E SILVA, 2011, p. 582).

Este gênero literário se distingue do gênero dramático e narrativo (embora, muitas vezes, a eles se misture mediante processos de fusão), principalmente devido ao fato de que não retrata a objetividade e a exterioridade do mundo, nem a interação do homem com este, mas sim o universo subjetivo, com questões voltadas à interioridade do leitor. Nas Orientações Curriculares para o Ensino Médio, lemos que a literatura, como uma arte, é vista como algo que faz cessar a primazia do trabalho alienado, que só o é para fins lucrativos, e é vista

como um meio de educação da sensibilidade; como meio de atingir um conhecimento tão importante quanto o científico - embora se faça por outros caminhos; como meio de pôr em questão (fazendo-se crítica, pois) o que 
transcender o simplesmente dado, mediante o gozo da liberdade que só a fruição estética permite; como meio de acesso a um conhecimento que objetivamente não se pode mensurar; como meio, sobretudo, de humanização do homem coisificado: esses são alguns dos papéis reservados às artes, de cuja apropriação todos têm direito. Diríamos mesmo que têm mais direito aqueles que têm sido, por um mecanismo ideologicamente perverso, sistematicamente mais expropriados de tantos direitos, entre eles até o de pensar por si mesmos (BRASIL, p. 52 e 53).

Paulino, Walty e Cury (1995) refletem sobre o texto poético e seu lugar na sociedade ocidental, ocupado basicamente com a produção e com a mais valia, na qual a poesia "é coisa para desocupados, loucos ou apaixonados; é para quem vive com a cabeça nas nuvens ou para um tipo especial de homem - o poeta" (PAULINO; WALTY; CURY, 1995 p. 86). Na verdade, essa noção é antiga. Desde Platão, o poeta é visto como alienado, pois não produz para sua sobrevivência, "e é acusado de subversivo porque propõe outras formas de ver o mundo, que não a imposta pelo sistema" (PAULINO; WALTY; CURY, 1995, p. 90).

Leminski, além de poemas, também escreveu ensaios e críticas acerca de diversos temas, e principalmente sobre a literatura/poesia. Em um ensaio de 1986, intitulado Inutensílio, o poeta tece uma crítica a nossa sociedade, imersa na pressa e no utilitarismo, em que tudo tem de ser útil, dar lucro - "Tudo tem que ter um pra quê" (LEMINSKI, 1986, p.68). Ele aponta a poesia como uma "in-utilidade", que tem como função nos dar prazer, e que o ganho, obviamente não material, que ela nos dá é "o surgimento de novos objetos no mundo" (1986, p. 69), os quais enquanto significantes, geram em nós novos significados, nos dá um conhecimento que claramente não pode ser medido, mas que nos capazes de alargar nossas ideias e possibilidades a respeito do mundo. Esse ganho, diferentemente do lucro, tão essencial ao capital, não depende da mais-valia na relação com o trabalho nem tampouco com a racionalidade subjecente à lógica produtiva capitalista.

\footnotetext{
a vida varia

o que valia menos

passa a valer mais

quando desvaria (LEMINSKI, 1985, p. 79)
} 


\section{O HAICAI: DA TRADIÇÃO AO ESTILO LEMINSKIANO}

Em que pese o fato de ter imigrado para o ocidente há mais de um século e ter experimentado muitas mudanças em sua forma, o haicai clássico japonês tem 17 sílabas, em três versos de 5, 7 e 5 sílabas. Tradicionalmente, no Japão, os haicais eram impressos em uma linha vertical e frequentemente havia uma pintura que o acompanhava. No haicai japonês tradicional não havia rima, nem título. Em sua estrutura apresentava duas partes que se contrapunham. O primeiro verso poderia apresentar uma ideia de oposição ao segundo e terceiro, ou ainda os dois primeiros versos terem um elemento de contraposição ao terceiro. O poema se referia a um momento presente, captando um flagrante da natureza e fazia referência a uma das quatro estações do ano, o que se chama de kigo, que pode indicar quando foi escrito, uma vez que o kigo representava o momento preciso, a sensação particular que deu origem a uma dada emoção e, permitia criar a característica que envolve e confere significado a uma sensação.

$\mathrm{O}$ autor de maior notoriedade nesse gênero na poesia japonesa foi o mestre Matsuo Bashô (1644 - 1694), que desde criança, quando era pajem, compartilhava do apreço pela poesia junto com seu senhor feudal. Bashô foi o poeta mais famoso de seu período, dedicando-se a fazer do haicai uma prática espiritual, na qual se percebe a essência de sua poesia ao prover alguns elementos mínimos, fazendo com que o leitor contemple e interaja diante dos espaços vazios deixados.

Paulo Leminski não foi o iniciador deste gênero poético no Brasil. As primeiras notícias que se tem da poesia japonesa nestas bandas é através de um livro de 1897, chamado Da França ao Japão, de Francisco Antônio Almeida, e também com a chegada dos primeiros imigrantes japoneses no início do século XX. Logo em seguida, no decurso do primeiro momento do modernismo brasileiro, uma época de inovação na literatura, Oswald de Andrade publica o livro Pau Brasil, em cuja apresentação, feita por Paulo Prado, acontece, segundo Paulo Franchetti, "a história do primeiro momento de assimilação do haicai japonês à literatura brasileira." (2008, p. 257).

Contudo, o primeiro autor brasileiro a compor haicais foi Afrânio Peixoto, num volume de 1919, intitulado Trovas populares brasileiras, no qual assimilou o haicai à trova popular, apresentando-o como um "epigrama lírico". Além de difundir o haicai em português, o autor também traduziu alguns dos mais significativos haicais de Bashô. 
Venceslau de Morais (1854 - 1929), assim como Afrânio Peixoto, também é considerado como marco inicial da difusão do haicai aqui no Brasil, com seu livro Relance da alma japonesa, de 1928.

Quem disseminou o haicai, no entanto, foi Guilherme de Almeida, na década de 1930. Embora modernista, fez o seu haicai mais próximo da sua vertente tradicionalista do começo do século do que propriamente dentro da estética vanguardista. Guilherme de Almeida utilizou, em sua adaptação, duas características formais do haicai: "a distribuição das palavras em três segmentos frasais (que ele identificou ao verso, medido à maneira portuguesa) e a composição por justaposição de duas frases, numa estrutura tópico/comentário" (FRANCHETTI, 2008, p. 261). Criou sua própria forma de fazer haicais, modificando sua estrutura ao acrescentar rimas, principal característica de seus haicais, de forma que os versos de cinco sílabas rimem entre si e, no verso de sete sílabas, a rima fique na segunda e sétima sílaba. Também agregou título aos poemas, fazendo com que perdessem a essência de um haicai, possibilitando até mesmo duas leituras, uma com e outra sem o título.

$\mathrm{Na}$ esfera do movimento concretista, destaca-se Pedro Xisto, autor de uma coletânea no volume Partículas, de 1984, e também Haroldo de Campos, com traduções de haicais de Bashô que, segundo Franchetti (2008, p. 264) revestiam-se de uma "excessiva ênfase na técnica compositiva e de um descolamento daquilo que constitui e condiciona boa parte da forma mesma do haicai na tradição de Bashô".

$\mathrm{Na}$ esteira de Xisto e Haroldo de Campos, Millôr Fernandes, com uma linguagem satírica, escrevia haicais humorísticos, fazendo uso das rimas. Tem como principal característica compor um dito espirituoso, cuja ironia e coloquialidade são uma regra, ficando próximo da poesia de Oswald de Andrade, agregando aos seus haicais o traço do poema-piada do Modernismo brasileiro.

Estes foram os principais difusores desse gênero no Brasil. Alguns mais tradicionalistas, defensores do conteúdo do haicai, que valorizavam algumas características particulares desse gênero, tais como uma linguagem simples e sem rima, com concisão, condensação e intuição, e a emoção. Outros mais inventivos, incorporando ao modelo tradicional novas características, de modo que atualmente, no Brasil, pode-se dizer que coexistem os haicais tradicionalistas, os de inspiração zen, os de cunho guilhermino, o epigramático e o concretista. 
Na década de 1980, Paulo Leminski foi o maior divulgador do haicai no Brasil, mesclando em sua obra influências da contracultura dos anos 1960 (o que deu à sua poesia um tom marginal e rebelde), da geração beat norte-americana e também do concretismo brasileiro. Do Concretismo, entretanto, Leminski não absorveu o lado racionalista dessa tendência, mas sim como ele próprio afirmou, extraiu daquele movimento a "loucura que aquilo representa, a ampliação dos espaços da imaginação e das possibilidades de novo dizer, de novo sentir, de novo e mais expressar". (BONVINCINO, 2004, p. 24). Aliada a estas experiências adquiridas com o concretismo, os haicais de Leminski apresentam características muito peculiares, que vão desde representações de um cotidiano urbano moderno a jogos de linguagem e pensamento associados a um humor ligeiro e inteligente, que evocam características dos poemas-piada de modernistas como Oswald de Andrade.

De acordo com Franchetti (2008), Leminski conseguiu aproximar a experiência poética japonesa ao que os poetas da chamada geração marginal propunham, isto é, uma poesia intimamente ligada ao cotidiano:

o seu haicai representa um momento de espetacular
adaptação da forma e do gênero ao português, (...) de
vê-lo como um caminho de vida, uma forma de trazer
a poesia para dentro do cotidiano, identificando-a à
exteriorização elegante e bem-humorada da experiência
sensória mais elementar (FRANCHETTI, 2008, p.266).

Outro traço característico dos seus haicais é a auto-reflexividade - frequentemente o tema é o próprio código da poesia. Leminski tinha uma preocupação com o fazer poético e muitos de seus poemas empregam a metalinguagem como recurso para revelar ao leitor essa autorreflexão, pois, para ele, o poeta, na feitura do poema, eleita-se em mostrar ao leitor como as palavras são sedutoras enquanto significantes, isto é, na sua dimensão sensorial. No debate que segue o seu ensaio Poesia: a paixão da linguagem, de 1986, Leminski declarou que:

1 Disponível em https:// artepensamento.com.br/ item/poesia-a-paixao-dalinguagem/Acesso em 3 de maio de 2019 ser poeta é ter nascido com um erro de programação genética que faz com que, em lugar de você usar as palavras para apresentar o sentido delas, você se compraz em ficar mostrando como elas são bonitas, têm um rabinho gostoso, são um tesão de palavra. ${ }^{1}$

Entretanto, em que pese esse grande espaço reservado ao humor e à reflexão metalinguística nos seus haicais, Leminksi não subestima 
aquela que é a característica que mais define o haicai: a sua dimensão imagética. Segundo o poeta:

\begin{abstract}
o haicai valoriza o fragmentário e o 'insignificante', o aparentemente banal e o casual, sempre tentando extrair o máximo do significado do mínimo de material, em ultrasegundos de hiper-informação. De imediato, podemos ver em tudo isso os paralelos profundos com a estética fotográfica. Esses traços característicos do haicai podem ser transpostos sem nenhuma dificuldade para a fotografia (LEMINSKI, 1986, p. 115).
\end{abstract}

O haicai capta o mundo exterior e funciona como um recorte da natureza, assim como a fotografia capta o momento por meio de uma lente objetiva, prescindindo mesmo do olhar humano. Sobre esta relação do haicai com a fotografia, Leminski escreveu que "O mundo que o haicai procura captar é um mundo objetivo, o mundo exterior. Um mundo de coisas onde o eu está quase sempre ausente, sujeito oculto, elidido" (LEMINSKI, 1986, p. 115). O objetivo é capturar a essência do lugar e do momento, a partir do ato contemplativo, dando ênfase na transformação, na dinâmica das cores, nas estações do ano, na união com a natureza, na conciliação do efêmero com o eterno. O efeito final é proporcionado pelo elemento surpresa, que libera a imaginação para o misterioso e o inefável jogo que ocorre na intersecção do familiar e desconhecido.

Percebe-se, enfim, que Leminski, embora tenha extraído do haicai japonês a concisão da forma, nem sempre se manteve nos limites da estética japonesa, ou seja, não se restringiu ao simbolismo objetivo de notação sensorial, restrito ao renovar das estações, mas acrescentou a possibilidade do humor, construído de forma inusitada. Seus haicais apropriam-se de novas formas de expressão e linguagem, exploram aspectos da palavra como a oralidade, ou apresentam uma visualidade que investe na comunicação com o cotidiano do leitor.

Como completa Barthes (1987, p. 29): “O prazer do texto é esse momento em que meu corpo vai seguir suas próprias ideias - pois meu corpo não tem as mesmas ideias que eu".

Outros problemas em relação ao ensino do gênero lírico, segundo observa Pilati (2017, p. 23), são: “i) tratá-la como pretexto para discutir conteúdos de outros domínios do conhecimento científico, artístico, teórico ou filosófico; ii) tratá-la como um mero arranjo de técnicas da linguagem poética, que seria de resto refratário ao mundo exterior" 
Para Pilati (2017, p. 26), o maior desafio posto é "Pensar como a poesia deixaria de ser coadjuvante de outros conteúdos e contextos e passaria ao protagonismo da ação didática em aulas que têm por objetivo transmitir o conhecimento atinente à literatura de modo específico", ou seja, o caminho que se deve seguir para o trabalho com a poesia em sala de aula é o de "desescolarizá-la", deixar de passar para os alunos leituras prontas de poemas. Tornar a poesia a protagonista da aula é o primeiro passo para inserir a poesia em sua real função.

\section{O HAICAI LEMINSKIANO COMO INICIAÇÃO AO LETRAMENTO LITERÁRIO NA ESCOLA}

Por trás de uma aparente facilidade, os haicais de Paulo Leminski escondem algo mais complexo, como a autoconsciência do fazer poético, o diálogo intertextual com a tradição (inclusive a oriental), a incorporação radical do coloquial, a técnica de (des) montagem, etc. Tais aspectos demandam um exercício de leitura ao mesmo tempo lúdico e produtivo, pois revelam um autor consciente da materialidade da linguagem e apto a ver o signo linguístico a partir de uma perspectiva dialógica e interativa com outras linguagens. Portanto, é de se esperar que nessa fronteira entre a simplicidade e a complexidade de seus haicais se produza uma leitura que fecunde as dimensões emotiva e cognitiva dos jovens leitores.

Leminski tem uma produção de haicais com temas variados. Sua obra sofreu várias influências, e a análise da construção composicional de alguns haicais, enquanto forma e conteúdo, com o propósito de estudar as possibilidades de se usá-los para as aulas de leitura e produção textuais, torna-se uma excelente estratégia para a iniciação do leitor na leitura do gênero lírico.

A título de demonstração do potencial de leitura que essa forma poemática mínima pode ter em uma aula, e a fim de revelar as possibilidades de leitura e as estratégias de produção de sentidos que podem der desencadeadas a partir do cotejamento dos níveis da expressão e do conteúdo, serão examinandos a seguir dois haicais do poeta-samurai.

Neste primeiro haicai, que se encontra na seção Desarranjos florais, de Distraídos venceremos, podemos perceber a existência de um kigo, a lua, que é um elemento simbólico da natureza e, sob 
a perspectiva literária, pode também ser entendido como um objeto fonte de inspiração do poeta, que incorpora a beleza, o misticismo, o romantismo, a idealização.

\author{
lua à vista \\ brilhavas assim \\ sobre auschwitz? \\ (LEMINSKI, 1995, p. 78).
}

Ao ler o primeiro verso, "lua à vista", se é levado, quase que involuntariamente, a relacioná-lo à expressão "terra à vista", que remete para a situação alvissareira de quem, após muito tempo em alto mar, tem a visão do porto de chegada. Do mesmo modo, neste haicai, o satélite noturno despontando brilhante no céu também pode ser visto como sendo alvissareiro, aprazível e inspirador de amparo e esperança para o eu-lírico que está a contemplá-lo. À maneira do haicai tradicional, está posta no primeiro verso uma situação em relação à qual os dois versos seguintes farão um contraponto.

Diante da beleza do astro e do que seria um instante de contemplação estética e desinteressada, emerge uma inquietação no espírito do poeta. O genocídio dos judeus na Segunda Guerra Mundial promovido por Hitler é relembrado por uma perspectiva não testemunhal do eu-lírico, que se interroga se esta mesma lua que brilha ali para ele, companheira dos poetas e inspiradora de sentimentos líricos, também brilhava em Auschwitz para os prisioneiros da guerra como algo alvissareiro que lhes trouxesse esperança em suas vidas.

O poema sugere que o plano estético não se esgota em si mesmo como deleite puro e auto-satisfação alienante. Antes, a contemplação meditativa do eu lírico o leva a refletir sobre a história. A escolha do autor por Auschwitz, e não por algum outro campo de concentração se deve, talvez, ao fato de que, sendo este o que teve o maior número de extermínios, evoca a lembrança do Holocausto, ato horroroso que contrasta com o brilho da lua. Estas contraposições (outras poderiam emergir) se oferecem como oportunidade de junto com os alunos refletir sobre a natureza, representada na impassibilidade da lua, e a história, com seu chamado à tomada de posição.

A poesia de Paulo Leminski constrói-se sobre uma mescla de artifícios de linguagem que incorpora elementos da alta e da baixa cultura, o que pode se prestar muito bem ao trabalho didático de se 
REVISTA DO PROGRAMA DE PÓS-GRADUAÇÃO EM COMUNICAÇÃO, LINGUAGENS E CULTURA DA UNIVERSIDADE DA AMAZÔNIA

da literatura, a fim de possibilitar relações entre o seu universo de conhecimentos e seu repertório de leituras com a tradição literária. Leminski, por meio de seus poemas, realiza uma síntese entre, de um lado, o rigor da construção formal, resultante de uma formação erudita e eclética que vai de Bashô aos concretistas, passando por Mallarmé, Pound, Joyce, entre outros, e de outro, a tradição das formas populares, visível na influência melódica da canção popular, dos recursos visuais da publicidade, dos provérbios, trocadilhos, gírias e palavrões do universo coloquial.

Pode-se dizer que sua arte funda-se na ideia do trabalho com a linguagem antes de tudo, mas que também abrange uma gama imensa de interesses da vida cotidiana: do político ao existencial, do humorístico ao amoroso, do circunstancial ao metafísico. Desse modo, a obra de Paulo Leminski ganha um contorno bastante singular que o torna um "poeta-síntese" dos anos 1970, como afirmou Regis Bonvicino em um artigo publicado em um artigo publicado no Jornal Folha de São Paulo, em 1989, dois dias após a sua morte ${ }^{2}$. Tendo vivido no contexto da pós-modernidade, sua identidade literária se dilui num denso amálgama de diferentes culturas, obliterando as oposições binárias tão caras ao pensamento ocidental moderno, como se depreende deste haicai presente em sua obra La vie em rose, de 1991:

$$
\begin{aligned}
& \text { nu como um grego } \\
& \text { ouço um músico negro } \\
& \text { e me desagrego }
\end{aligned}
$$

(LEMINSKI, 1991, p. 147)

$\mathrm{Na}$ forma extremamente concisa desses três versos, Leminski procede a uma desconstrução do sujeito moderno, num movimento muito afinado com as ideias de algumas perspectivas teóricas que estão na base do pensamento pós-moderno, como as teorias pósestruturalistas e as pós-coloniais, que passaram a questionar as bases da noção de um sujeito autônomo, coerente, centrado em um ego cogitante do tipo cartesiano, e a desafiar as concepções racionalistas que desde a origem da modernidade predominaram nas formulações sobre o que ou quem é o sujeito na sociedade ocidental.

No haicai acima, a formulação proposta nos dois primeiros versos apontam para a configuração de um sujeito dividido entre duas matrizes de civilização e cultura: a branca e a negra. O verso "nu como um grego" simboliza de maneira muito imagética e
2 Bonvicino, R. "Morre Leminski. poetasíntese dos anos 70", In Folha de S. Paulo, 9 de junho de 1989. 
paradigmática o homem europeu e branco, como uma figura heráldica do período helênico. Assim, em uma leitura a ser feita com os alunos pode-se, lançando mão de imagens de figuras masculinas daquele período presente em afrescos, objetos, esculturas, construir um modelo de sujeito e de cultura e civilização.

A partir desse modelo, que é o modelo eurocêntrico, pode-se refletir sobre o conflito latente na situação apresentada, quando se introduz segundo o verso: "ouço um músico negro". Tem-se aí outro modelo, o homem não branco, não europeu, simbolizando por meio da música toda a cultura de origem africana. Sabe-se que historicamente o branco europeu, além de impor sua cultura sobre o negro africano, não parava para ouvi-lo: sua música, literatura, tradições, etc, eram silenciadas devido a sua condição subalterna. Entretanto, no aqui e agora do enunciado do poema, que é o Brasil da década de 1980, esse sujeito branco está nu, o que dá margem a muitas interpretações, como as de exposição, desvelamento, despojamento, entre outras. É comum, inclusive, na modernidade ver associada a ideia de nudez aos sujeito africanos, e nesse momento professor e alunos podem entregarse à semiótica de algumas imagens que expuseram e estereotiparam os homens, mulheres e crianças africanas como signos da nudez. Para desconstruir esse estereótipo, seria interessante chamar a atenção para o primeiro verso e refletir sobre a importância do corpo e da nudez para a cultura grega, também valendo-se de imagens de afrescos e estatuárias daquele período.

Finalmente, ao introduzir o último verso, "e me desagrego", o percurso da leitura pode se concluir com o desmonte, a desconstrução, dos dois modelos, mas, sobretudo, interrogar-se sobre o verbo desagregar, em cuja ação reflexiva o eu lírico se descobre um outro sujeito, não mais grego (aqui seria oportuno chamar a atenção dos alunos para a função do prefixo des que dá ao verbo o sentido de deixar de ser grego, num claro jogo de trocadilho), não mais branco, não mais europeu.

\section{CONSIDERAÇÕES FINAIS}

Em que pese a brevidade das leituras feitas acima, é possível dizer que os haicais de Leminski, a despeito de uma aparente simplicidade, escondem uma riqueza de sentidos que pode desdobrar-se em leque polissêmico. Por se tratar de uma forma concisa de estrutura breve, o haicai presta-se muito bem a um processo indispensável na formação 
do leitor: a releitura ou, melhor dizendo no plural, as releituras, que podem ser inúmeras, estimulando, assim, o jovem leitor de poesia a perscrutar o texto em interrogações sucessivas. Afinal, o haicai, por sua brevidade, serve contraditoriamente à leitura sem pressa, permeada por momentos de contemplação diante do texto, como se diante da esfinge estivesse o leitor desafiado à arte da decifração.

Trabalhar com a compreensão sobre o trabalho poético pressupõe o entendimento de que, diferentemente do que acontece com a língua na dimensão pragmática da comunicação, na linguagem poética a validade do familiar do leitor é suspensa e sua participação ativa nos vazios do texto é fundamental para a fruição da experiência estética.

É nesta linha tênue entre a aparente facilidade e a multiplicidade composicional deste autor que situamos o instante em que o leitor vai formar suas perspectivas emocionais e cognitivas. Reafirmando o que foi dito inicialmente, este momento da experiência com a leitura literária é imprescindível e deve acontecer tão cedo quanto possível, de modo que ocorra gradualmente um afloramento da sensibilidade estética do jovem leitor. Assim, por meio da sensação de estranhamento que o texto poético provoca, sua sensibilidade e sua curiosidade se aguçam, seu conhecimento do código linguístico e seu horizonte cultural amplificam-se, contribuindo para a sua humanização.

O professor, como mediador de conteúdos e processos e não mero transmissor, tem um importante papel nesta formação do leitor literário, pois ao interagir com os alunos, tanto a partir de suas próprias experiências literárias como as deles, pode então formar leitores capazes de terem mais opções ao formular seus pensamentos e se posicionarem diante da sociedade na qual estão inseridos.

\section{REFERÊNCIAS}

BRASIL, Ministério da Educação. Secretaria da Educação Básica. Orientações curriculares para o ensino médio: linguagens códigos e suas tecnologias. Vol.1. Brasília: MEC/SEB, 2006.

CÂNDIDO, Antonio. A literatura e a formação do homem. Ciência e Cultura, v. 24, n. 9, 1972. Disponível em: https://pt.scribd.com/presentation/291912956/ CANDIDO-A-Literatura-e-a-Formacao-Do-Homem. Acesso em 24 de junho de 2018.

DELL'ISOLA, Regina Lúcia Péret A interação sujeito-linguagem em leitura. n. 2830 (1994). Cadernos de Teoria da Literatura. UFMG. Disponível em: http:// periodicos.letras.ufmg.br/index.php/cltl/article/view/10220. Acesso em $24 \mathrm{de}$ junho de 2018. 
FRANCHETTI, Paulo. O Haicai no Brasil. Alea Estudos Neolatinos, volume 10, número 2, p.256-269, Julho-Dezembro 2008. Disponível em: https://pt.scribd.com/ document/176297987/o-Haicai-No-Brasil-franchetti. Acesso em 24 de junho de 2018 .

JAUSS, Hans Jauss. A História da Literatura como provocação à teoria literária. Tradução de Sérgio Telloroli. São Paulo: Ática, 1994.

KLEIMAN, Angela. B. Letramento e suas implicações para o ensino de língua materna. Signo, Santa Cruz do Sul, v. 32, n. 53, p. 1-25, jul. 2007. ISSN 1982-2014. Disponível em: <https://online.unisc.br/seer/index.php/signo/article/view/242/196>. doi:http://dx.doi.org/10.17058/signo.v32i53.242. Acesso em: 24 de junho de 2018.

LEMINSKI, Paulo. Caprichos \& Relaxos. 3 ed. São Paulo: Brasiliense, 1985. . Anseios crípticos. Curitiba: Editora Barba Ruiva, 1986. . La vie em close. 1 ed, 6 reimpressão. São Paulo: Brasiliense. 1991. 1995. . Distraídos Venceremos. 1 ed, $6^{\text {a }}$ reimpressão. São Paulo: Brasiliense. Toda Poesia. São Paulo: Companhia das Letras. 2013.

LEMINSKI, Paulo e BONVINCINO, Régis. Organização de Régis Bonvicino, com a colaboração de Tarso M. de Melo. Envie meu dicionário: cartas e alguma crítica. 2 ed. São Paulo: Editora 34, 1999.

ORLANDI. Eni. P. Discurso e Leitura. $4^{\mathrm{a}}$ ed. São Paulo, Cortez; Campinas: Editora da Universidade Estadual de Campinas, 1999.

PILATI, Alexandre. Poesia na sala de aula: subsídios para pensar o lugar e a função da literatura em ambientes de ensino. Campinas: Pontes Editores, 2017.

PAULINO, Graça; WALTY, Ivete. Teoria da literatura na escola: atualização para professores de I e II graus. Belo Horizonte: Ed. Lê, 1994.

ROUXEL, Annie. Mutações epistemológicas e o ensino da literatura: o advento do sujeito leitor. Tradução de Samira Murad, Revista Criação \& Crítica, n. 9, p. 13-24, nov. 2012. Disponível em: $<$ http://www.revistas.usp.br/criacaoecritica $>$. Acessado em 07 de dezembro de 2013.

SILVA, Vitor Manuel de Aguiar. Teoria da Literatura. Coimbra: Almedina, 2011.

ZAPPONE, Mirian Hisae Yaegashi. A leitura de poesia na escola. In: MENEGASSI, Renilson José (Org.) Leitura e ensino. 2 ${ }^{\mathrm{a}}$ ed. Maringá: Eduem, 2010.

Recebido em 02 Out 2019 ～Aprovado em 03 Nov 2019

Sérgio Roberto MASSAGLI

Doutor em Estudos Literários pela Universidade Estadual Paulista Júlio de Mesquita Filho. Mestre em Literatura Comparada pela Michigan State University.. Docente da Universidade Federal da Fronteira Sul (UFFS). Tem experiência na área de Letras, com ênfase em Teoria e Crítica Literária, atuando principalmente nos seguintes temas: intertextualidade, teorias da recepção, literatura, história e memória, e representações do espaço urbano na literatura. E-mail: massagli@hotmail.com

\section{Maiara Cristina MARAFON}

Graduada pela Universidade Federal da Fronteira Sul - UFFS no curso de Licenciatura em Letras - Português e Espanhol. Tem experiência na área de Letras, com ênfase em ensino de poesia. Foi voluntária no de Projeto de Extensão de Monitoria em Estudos da Língua Espanhola e bolsista no projeto de pesquisa "Vida afora, verso adentro: a aventura leminskiana em Distraídos venceremos". E-mail: maiara.cm@hotmail.com 